\title{
FREQUENCY OF ANAEROBIC POWER AMONG BRAZILIANS BASED ON DERMATOGLYPHICS AND R577X POLYMORPHISM OF THE ACTN3 PROTEIN
}

\author{
Carlos Renato Paz ${ }^{1,3,6}$, Ramon Cunha Montenegro ${ }^{1,2,3}$, Eric de Lucena Barbosa ${ }^{1,2,6}$, \\ Asdrúbal Nóbrega Montenegro-Neto ${ }^{2}$, Sérgio Marques de Lucena ${ }^{4}$, \\ Vanduir Soares de Araújo Filho ${ }^{2,4,6}$, Paula Roquetti Fernandes ${ }^{5,6}$, and José Fernandes Filho ${ }^{1,5,6}$ \\ ${ }^{1}$ Autonomous University of Asunción - UAA/Asunción-PY; Paraguay \\ ${ }^{2}$ Physical Evaluation Laboratory - UNIPÊ - SANNY, João Pessoa, Paraíba, Brazil \\ ${ }^{3}$ Federal Institute of Education, Science and Technology of Paraíba - IFPB, João Pessoa, \\ Paraíba, Brazil \\ ${ }^{4}$ Scientific Policing Institute of Paraíba SPI-PB, João Pessoa, Paraíba, Brazil \\ ${ }^{5}$ Center of Excellence in Physical Evaluation - CEAF, Rio de Janeiro, Brazil \\ ${ }^{6}$ LABIMH-UFRJ - Research Group, Rio de Janeiro, Brazi
}

\begin{abstract}
SUMMARY
Dermatoglyphics and analysis of the Alpha-Actinin-3 gene are evaluative instruments frequently used to identify the sportive and general population profile associated with physical performance. This research aimed to determine, based on dermatoglyphic characteristics and the R577X polymorphism of Alpha-Actinin-3, the percentage of people in the State of Paraíba/Brazil, with unfavorable characteristics to excelling in sports that require anaerobic power. A descriptive study of profiles, with ex post facto typology, was performed. The dermatoglyphic fingerprint characteristics of 309 people (149 males and 160 females) were identified, and ACTN3 genotype was analyzed in 96 people (40 males and 56 females). The dermatoglyphic data indicated that $5.8 \%$ of the study population fit the classification of anaerobic muscle power predisposition, while $94.2 \%$ did not fit on it. The genetic frequency analysis indicated that $19.8 \%$ of subjects in the sample had the XX mutant genotype. These results represent a substantial error reduction in the search for and selection of athletes with the potential for high performance, especially in those sports that require AMP.
\end{abstract}

Key Words: Alpha-actinin, Fingerprint, Genetic Polymorphism, Skeletal Muscle, Genotype frequency.

\section{INTRODUCTION}

The search for sports talent is a phenomenon that have been constant growing and brings with it precocious investments in potential elite athletes. Therefore, the use of adequate and specific evaluative instruments is fundamental to identifying promising athletes. These instruments help to reduce the chances of mistakes and excessive financial expenses by increasing the likelihood of identifying athletes that are capable of achieving a high level of performance in particular sport modalities (Kansal, 2010).

One evaluative method being used to characterize high-performance athletes is dermatoglyphics, an approach that involves the analysis of the patterns made by dermal papillae originating from the neurovascular region. These patterns are formed since the womb period and remain unchanged throughout life. This form of analysis establishes strong correlations between dermatoglyphic features and particular physical qualities, offer an inexpensive evaluation, and is highly reproductible (Abramova, Nikitina, \& Ozolin, 1996; Junior, Cunha, Scheneider, \& Dantas, 2006; Kücken \& Newell, 2005; Zary \& Fernandes-Filho, 2007; Zary et al., 2010).

The immutability of fingerprints allows their configurations analysis from childhood, making this method a valuable tool for identifying and training 
potential individuals at all levels of human development, from beginning level to elite level sports (Bogle, Reed \& Norton, 1994; Cummins \& Midlo, 1961; Linhares et al., 2009).

Successful performance in certain sport modalities requires good Anaerobic Muscle Power (AMP). This physical property is related to the gene that encodes $\alpha$-actinin isoform 3 (ACTN3), which is specific to type II rapid contraction fibers. ACTN3 is an actinbinding protein which is part of the $\mathrm{Z}$ line of the sarcomere; it assists in the organization and maintenance of the contractile apparatus, and in the arrangement of myofibrils (Macêdo \& Fernandes-Filho, 2003; Mills et al., 2001; North et al., 1999; Holdys, Kryściak, Stanisławski, \& Gronek, 2011; Papadimitriou, Papadopoulos, Kouvatsi, \& Triantaphyllidis, 2008).

The 577R allele of the ACTN3 gene produces active ACTN3 protein in RR homozygotes and RX heterozygotes. These genotypes are favorable for anaerobic activity and are associated with elite and Olympic sprinter athletes. The ACTN3 R577X polymorphism can also be identified in childhood and determining the genotype for this locus can provide information about an individual's genetic predisposition for AMP (Druzhevskaya, Ahmetov, Astratenkova, \& Rogozkin, 2008; Eynon et al., 2009; Moran et al., 2007; Yang et al., 2003).

The presence of active ACTN3 is not vital to the human body since $\alpha$-actinin isoform 2 (ACTN2) can satisfactorily make up for its absence in normal daily functioning. However, the absence of ACTN3 appears to hinder athletic muscular performance in terms of anaerobic muscle power; and XX genotype individuals are generally not found among elite athletes participating in events that require this physical quality to excel (Bustamante-Ara et al., 2010; Norman et al., 2009; Roth et al., 2008; Scott et al., 2009).

By determining the dermatoglyphic profile and the polymorphism R577X of the ACTN3, the goal of this study was to assess the percentage of people living in the State of Paraíba/Brazil that would not be good candidates for sports that require AMP.

\section{METHODS}

\section{Study Design and Subjects}

The sample of this study was randomly selected among 7-17 years old students living in the State of Paraíba/Brazil. Descriptive profiles were compiled with an ex post facto typology which identified the fingerprint characteristics of 309 subjects (149 boys and 160 girls); among these, 96 subjects (40 boys and 56 girls) were genotyped for ACTN3.
Digital impressions (DIs) and cells from the oral mucosa were collected at the UNIPE/SANNY Laboratory of the Physical Education Course of the University of João Pessoa - UNIPÊ, by one researcher (C.R.P.). The biological material collected were then passed on to the laboratory complex of the Scientific Policing Institute of the State of Paraíba (SPI/ $\mathrm{PB})$.

The research was approved by the Human Research Ethics Committee of the Lauro Wanderley University Hospital (EC/LWUH) under protocol no 677-10. Written free and informed consent forms were obtained from all the parents and guardians in compliance with the 1975 Helsinki Declaration.

\section{Protocol for dermatoglyphic data collection and analysis}

DIs were collected and analyzed following as described by (Cummins \& Midlo, 1961). Forensicgrade flat and rolled DIs were captured using a Cross Match ${ }^{\circledR}$ Verifier 320 LC scanner linked to a computer. The DIs were classified as having no delta Arch (A) patterns, single delta Loop (L) patterns, and two deltas Whorl (W) patterns.

Next, the number of deltas on the ten digits (D10) of the hands was identified from their sum. The summation total quantity of lines (STQL) was obtained by counting the lines present between the deltas and the DI nuclei on all the fingers, discounting the first and final line.

Individuals were designated as not having a predisposition for AMP if they did not have the dermatoglyphic characteristics for AMP described by (Abramova, Nikitina and Ozolin, 1996): $\mathrm{A}=1$ or 2; $\mathrm{L}=7$ or $8 ; \mathrm{W}=1$ or $2 ; \mathrm{STQL} \leq 134$, and $\mathrm{D} 10 \leq 13$.

\section{Protocol for ACTN3 genotype data collection and analysis}

The biological material used to analyze the ACTN3 R577X polymorphism came from oral mucosa cells that were collected using a sterile cotton bud that was swabbed in the internal cavity of the mouth until the cotton absorbed the saliva. The collected material were subjected to DNA extraction as described by (Walsh, Metzger, \& Higuchi, 1991). Genotypes were determined by employing real-time polymerase chain reactions (PCRs) using an IQ5 Thermal Cycler (Biorad) PCR machine with a kit designed to reveal the R577X polymorphism (Assay Id C5900931-Applied Biosystems).

\section{Statistical Analysis}

Descriptive statistics were used to represent the dermatoglyphic frequencies of A, L, W, D10, and 
STQL, as well as the frequencies of the ACTN3 R577X polymorphism as determined by gene counting. The frequencies were represented as percentage values. All analyses were performed using the Statistical Package for the Social Sciences (SPSS), Version 14.0.

\section{RESULTS}

\section{Dermatoglyphic Profiles}

Of the 309 subjects examined, 291 (94.2\%) were classified as not predisposed to AMP according to their dermatoglyphic profiles. Within this group it was found individuals with physical characteristics associated with a high resistance to speed (14\%), pure force $(4.1 \%)$, endurance $(46.9 \%)$ and motor coordination $(29.2 \%)$. Only $18 / 309(5.8 \%)$ of the sample presented a dermatoglyphic profile suggestive of a propensity for sports that require high-power muscle contraction.

\section{ACTN3 Genotyping}

Of the 96 subjects investigated for which ACTN3 genotype information was determined, (19.8\%) were XX homozygotes, (47.9\%) were RX heterozygotes, and $(32.3 \%)$ were RR homozygotes. Thus, as both RR homozygotes and RX heterozygotes express the active form ACTN3, 80.2\% of the sample were not excluded from potentially having an AMP predisposition. The 19.8\% that were found to have the XX genotype were considered to be likely incapable of realizing contractions with high performance AMP.

\section{DISCUSSION}

This was a pioneering type of research in which was identified the relative frequency of individuals who do not have a predisposition to perform highpowered muscle contractions in a cohort of subjects in the State of Paraíba/Brazil, based on dermatoglyphics and ACTN3 polymorphism genotyping.

The dermatoglyphic classification approach was better able to identify people who are not predisposed to AMP (94.2\%) than ACTN3 analysis (19.8\%). However, it should be noted that the dermatoglyphic approach involved an associative analysis (Abramova, Nikitina, \& Ozolin, 1996), whereas subjects identified as having the XX genotype were identified as not being able to perform high strength performance contractions due to their lack of active ACTN3 protein, which affects in a functional way the contractile apparatus needed for rapid contraction (Roth et al., 2008; Scott et al., 2009).

\section{Dermatoglyphics}

The dermatoglyphic classification of individuals who are not predisposed to AMP stemmed from an analysis of qualitative and quantitative indexes obtained from the subjects' DIs. In a study of the dermatoglyphic characteristics of 122 adolescents, of both sexes, who were not athletes and who lived in the city of Resende - Rio de Janeiro/Brazil, (Klein \& FernandesFilho, 2003) found that approximately $59.0 \%$ of the subjects had dermatoglyphic patterns that did not favor AMP. In a similar 2003 study of 96 people living in the city of Niterói - Rio de Janeiro/Brazil, who had a similar profile as the subjects in Klein and Fernandes-Filho's (2003) study; Macêdo and FernandesFilho (2003) found that $76.0 \%$ of the subjects did not presented a predisposition for AMP. The percentage of subjects without a predisposition for AMP found in these prior Brazilian studies (Klein \& FernandesFilho, 2003; Macêdo \& Fernandes-Filho, 2003) was lower than that observed in this research.

Hence, the results obtained by the samples analyzed in the prior two Brazilian studies in Rio de Janeiro State (Klein \& Fernandes-Filho, 2003; Macêdo \& Fernandes-Filho, 2003) are not similar to the current findings from Paraíba in terms of the relationship of the relative frequency of those subjects with the dermatoglyphic characterisics for AMP. The findings of this research reinforce the results of previous studies in terms of the effectiveness of the dermatoglyphic method as an instrument for evaluating and determining population profiles of a predisposition for a physical activity, given the strong association between papillary patterns and physical qualities, both in adolescents and in high-performance athletes (Junior et al., 2006; Linhares et al., 2009; Zary \& FernandesFilho, 2007; Zary et al., 2010).

\section{ACTN3 genotyping}

Discussion of the ACTN3 polymorphism has centered mostly around the mutant XX homozygous genotype since it is this configuration that differentiates potential athletes in terms of their ability to produce active ACTN3 (Roth et al., 2008; Ruiz et al., 2010; Scott et al., 2009).

To place the current genotype findings in nowadays context, the percentage of XX genotype individuals revealed in the current study of a Brazilian cohort is compared to percentages obtained in studies performed in other geographical regions (Table 1).

Note that the finding of this study (of 19/96 subjects having the XX genotype at the 577 locus of the ACTN3 protein gene) is similar to the proportions 
TABLE 1

Comparison of frequencies of XX homoaygote genotype of the $\mathrm{R} 577 \mathrm{X}$ polymorphism of ACTN3 protein by country.

\begin{tabular}{llc}
\hline \multicolumn{1}{c}{ Study } & \multicolumn{1}{c}{ Country } & XX frequency $(\%)$ \\
\hline Paz et al., 2012 & Brazil & 19.8 \\
\hline Zempo et al., 2010 & Japan & 24.8 \\
\hline Norman et al., 2009 & Sweden & 19.0 \\
\hline Papadimitriou et al., 2008 & Greece & 18.2 \\
\hline Ruiz et al., 2011 & Spain & 18.3 \\
\hline Yang et al., 2003 & Australia & 18.0 \\
\hline Eynon et al., 2009 & Israel & 18.0 \\
\hline McCauley, Mastana, and Folland, 2010 & United Kingdom & 16.0 \\
\hline Druzhevskaya et al., 2008 & Russia & 14.2 \\
\hline Niemi, 2005 & Finland & 9.2 \\
\hline Scott et al., 2009 & Jamaica & 2.0 \\
\hline Scott et al., 2009 & United States & 4.0 \\
\hline
\end{tabular}

reported by (Ruiz et al., 2011) among physical education students, (Norman et al., 2009) for white men and women, (Eynon et al., 2009) white subjects, (Papadimitriou et al., 2008) for his control group, and (Yang et al., 2003) for healthy white children and adults. Studies with moderately lower ratios of XX genotype individuals have also been reported by (McCauley, Mastana, \& Folland, 2010) for men between 60-70 years of age, (Druzhevskaya et al., 2008) for white men and women, and (Niemi \& Majamaa, 2005) for his control group. And markedly lower ratios of XX genotype individuals were reported by (Scott et al., 2009) for Jamaican and US African American groups. Only a sample of post-menopausal women in Japan studied by (Zempo et al., 2010) showed a frequency of the mutant XX genotype $(24.8 \%)$ that was higher than that found in the present study.

Hence, with respect to the relative frequency of mutant XX homozygote polymorphism, this research obtained a frequency similar to that found in studies performed in various parts of the world (including studies in Sweden, Greece, Australia, Spain, and Israel) (Eynon et al., 2009; Norman et al., 2009; Papadimitriou et al., 2008; Ruiz et al., 2011; Yang et al., 2003), suggesting that the frequency of the XX genetic configuration does not vary greatly in the world's population.

In terms of the allele encoding the active form of ACTN3, the frequencies of RR and RX genotypes observed here were similar to those of several other studies, especially those in studies with more RX heterozygotes than RR homozygotes, including the findings of (Ruiz et al., 2011) RR 31.1\% and RX 50.6\%, (Zempo et al., 2010) RR 17.4\% and RX 57.8\%,
(Norman et al., 2009) RR 31\% and RX 50\%, (Eynon et al., 2009) RR 20.0\% and RX 62.0\%, Niemi \& Majamaa, 2005) RR 45.0\% and RX 45.8\%, (Yang et al., 2003) RR 30.0\% and RX 52.0\%, (Druzhevskaya et al., 2008) RR 36.8\% and RX 49.0\%, and (Papadimitriou et al., 2008) RR 25.97\% and RX 55.8\%. On the other hand, (McCauley, Mastana, \& Folland, 2010) RR 43.0\% and RX 41.0\% and (Scott et al., 2009), with control groups from Jamaica RR 75.0\% and RX $23.0 \%$ and US African Americans RR 66.0\% and RX 30.0\%, observed a higher proportion of the RR homozygote genotype.

The ACTN3 gene has become an important molecular genetic marker for predicting maximum athletic performance because of the association of the R577 allele with elite sprinters (Druzhevskaya et al., 2008; Eynon et al., 2009; Moran et al., 2007; Papadimitriou et al., 2008; Yang et al., 2003). Meanwhile, various studies have shown that the mutant XX homozygotes genotype is less frequently found in these athletes and that it can impact muscle performance in contractions requiring AMP (Berman \& North, 2010; Roth et al., 2008; Scott et al., 2009).

These presuppositions show the clear importance of identifying and excluding individuals who are homozygotes for the ACTN3 577X allele as a way of selecting subjects for sports that require AMP, once this genetic configuration, (which is present in around $18 \%$ of the world's population), is not typically found in high-performance sprinters. However, (Scott et al., 2009) observed that 2/46 athletes, who won medals in important international speed competitions or who broke world records, have the XX genotype. This phenomenon could be explained by a high level of 
ACTN2 compensation. Despite these exceptional cases, the XX genotype can be considered a genetic obstacle impeding success in sports that require AMPs.

The 577X allele might, however, boost the suitability of athletes for endurance intensive sports (Berman \& North, 2010; Eynon et al., 2009; Papadimitriou et al., 2008; Scott et al., 2009). Although (Moran et al., 2007) didn't find any evidence that this allele was associated with endurance.

The study made by (Ruiz et al., 2010) analyzed the ACTN3 R577X polymorphism and five other polymorphisms related to good performance in endurance sports (ACE I/D, AGT Met235Thr, GDF-8 K153R, IL6_174 G/C, and NOS3_786T_C) in a sample of power and endurance athletes and in a control group, all of whom were Caucasian. They found that the polygenic profile only partially differentiated power athletes from endurance athletes and controls. Their findings suggest that, even in a partial way, there is genetic variation, that can distinguish between and guide for better choices about in which sports some particular athletes would be predisposed to perform well in.

\section{CONCLUSION}

Both the dermatoglyphic and ACTN3 genotyping methods tested in this study demonstrated effectiveness in identifying individuals likely not ideally suited for AMP intensive sports. Dermatoglyphics revealed a much larger group of individuals as not innately predisposed to perform well in sports that require AMP than ACTN3 polymorphism genotyping. These results represent a substantial error reduction in the search for and selection of athletes with the potential for high performance, especially in those sports that require AMP. Ideally a combination of genetic markers related to physical performance should be employed to develop athletic potential profiles.

\section{ACKNOWLEDGMENTS}

We would like to offer our sincere thanks to Dr. Antonio Albuquerque Toscano for making the Forensic DNA Laboratory of the Scientific Policing Institute SPI/PB available for DNA analyses.

\section{REFERENCES}

Abramova, T. F., Nikitina, T. M., \& Ozolin, N. N. (1996). Dermatoglyphic prints. genetic markers in the potential energy of man. Moscow Scientific Annals, 3(13).
Berman, Y., \& North, K. N. (2010). A gene for speed: The emerging role of $\alpha$-actinin-3 in muscle metabolism. Physiology, 25, 250-259. doi: 10.1152/physiol.00008.2010; PMid: 20699471

Bogle, A. C., Reed, T., \& Norton, J. A. (1994). Within-pair differences in a-b ridge count asymmetry in monozygotic twins: evidence for a placental proximity effect. Hum Hered, 44, 162168. doi: 10.1159/000154209; PMid: 8039800

Bustamante-Ara, N., Santiago, C., Verde, Z., Yvert, T., Gómez-Gallego, F., Rodríguez-Romo, G., ... Lucia A. (2010). ACE and ACTN3 genes and muscle phenotypes in nonagenarians. Int J Sports Med, 31, 221-224. doi: 10.1055/s-00301247529; PMid: 20148371

Cummins, H., \& Midlo, C. H. (1961). Fingerprints, palms and soles: an introduction to dermatoglyphics. New York: Dover Publications Inc.

Druzhevskaya, A. M., Ahmetov, I. I., Astratenkova, I. V., \& Rogozkin, V. A. (2008). Association of the ACTN3 R577X polymorphism with power athlete status in Russians. Eur J Appl Physiol, 103, 631-634. doi: 10.1007/s00421-008-0763-1; PMid: 18470530

Eynon, N., Duarte, J. A., Oliveira, J., Sagiv, M., Yamin, C., Meckel, ... Goldhammer, E. (2009). ACTN3 R577X Polymorphism and Israeli Toplevel Athletes. Int J Sports Med, 30, 695-698. doi: 10.1055/s-0029-1220731; PMid: 19544227

Holdys, J., Kryściak, J., Stanisławski, D., \& Gronek, P. (2011). Polymorphism of the $\alpha$-actn 3 gene in individuals practising different sports disciplines. Biol Sport, 28, 101-106. doi: 10.5604/942738

Junior, A. T. C., Cunha, A. C. P. T., Scheneider, A. T., \& Dantas, P. M. S. (2006). Características dermatoglíficas, somatotípicas, psicológicas e fisiológicas da seleção brasileira feminina adulta de handebol [Features dermatoglyphics, somatotype, psychological and physiological of the Brazilian adult female handball]. Fit Perf J., 5, 81-86. doi: 10.3900/fpj.5.2.81.p

Kansal, D. K. (2010). A critical study of sports talent selection and promotion of sports participation, at young age. Br J Sports Med, 44, i65-i66. doi: 10.1136/bjsm.2010.078725.219

Klein, C. M. O., \& Fernandes-Filho, J. (2003). Relação entre a dermatoglifia, as qualidades físicas e o nível maturacional de escolares adolescentes de ambos os sexos. Fit Perf J, 2, 321-329.

Kücken, M., \& Newell A. C. (2005). Fingerprint formation. J Theor Biol, 235, 71-83. doi: 10.1016/j.jtbi.2004.12.020; PMid: 15833314 
Linhares, R. V., Matta, M. O., Lima, J. R. P., Dantas, P. M. S., Costa, M. B., Fernandes Filho, J. (2009). Efeitos da maturação sexual na composição corporal, nos dermatóglifos, no somatótipo e nas qualidades físicas básicas de adolescentes [Efeitos da maturação sexual na composição corporal, nos dermatóglifos, no somatótipo e nas qualidades físicas básicas de adolescentes]. Arq Bras Endocrinol Metab, 53, 47-54. doi: 10.1590/S0004-27302009000100008; PMid: 19347185

Macêdo, M. M., \& Fernandes-Filho, J. (2003). Estudo das características dermatoglíficas, somatotípicas e das qualidades físicas básicas nos diversos estágios de maturação sexual [Study of dermatoglyphic characteristics, somatotype and basic physical qualities in different stages of sexual maturation]. Fit Perf $J$, 2, 315-320. doi: 10.3900/fpj.2.6.315.s; doi: 10.3900/fpj.2.6.315.p

McCauley, T., Mastana, S. S., \& Folland, J. P. (2010). ACE I/D and ACTN3 R/X polymorphisms and muscle function and muscularity of older Caucasian men. Eur J Appl Physiol, 109, 269277. doi: 10.1007/s00421-009-1340-y; PMid: 20069311

Mills, M. A., Yang, N., Weinberger, R. P., Vander Woude, D. L., Beggs, A. H., ... North, K. N. (2001). Differential expression of the actinbinding proteins, $\alpha$-actinin- 2 and -3 , in different species: implications for the evolution of functional redundancy. Hum Mol Genet, 10, 1335-1346. doi: 10.1093/hmg/10.13.1335; PMid: 11440986

Moran, C. N., Yang, N., Bailey, M. E. S., Tsiokanos, A., Jamurtas, A., MacArthur, D. G., ... Wilson, R. H. (2007). Association analysis of the ACTN3 R577X polymorphism and complex quantitative body composition and performance phenotypes in adolescent Greeks. Eur J Hum Genet, 15, 88-93. doi: 10.1038/sj.ejhg.5201724; PMid: 17033684

Niemi, A. K., \& Majamaa, K. (2005). Mitochondrial DNA and ACTN3 genotypes in Finnish elite endurance and sprint athletes. EurJ Hum Genet, 13, 965-969. doi: 10.1038/sj.ejhg.5201438; PMid: 15886711

Norman, B., Esbjörnsson, M., Rundqvist, H., Österlund, T., von Walden, F., \& Tesch, P. A. (2009). Strength, power, fiber types, and mRNA expression in trained men and women with different ACTN3 R577X genotypes. J Appl Physiol, 106, 959-965. doi: 10.1152/ japplphysiol.91435.2008; PMid: 19150855
North, K. N., Yang, N., Wattanasirichaigoon, D., Mills, M., Easteal, S., \& Beggs, A. H. (1999). A common nonsense mutation results in alphaactinin-3 deficiency in the general population. Nat Genet, 21, 353-354. doi: 10.1038/7675; PMid: 10192379

Papadimitriou, I. D., Papadopoulos, C., Kouvatsi, A., \& Triantaphyllidis, C. (2008). The ACTN3 gene in elite Greek track and field athletes. Int J Sports Med, 29, 352-355. doi: 10.1055/s-2007965339; PMid: 17879893

Roth, S. M., Walsh, S., Liu, D., Metter, E. J., Ferrucci, L., \& Hurley, B. F. (2008). The ACTN3 R577X nonsense allele is underrepresented in elite-level strength athletes. Eur J Hum Genet, 16, 391-394. doi: 10.1038/sj.ejhg.5201964; PMid: 18043716; PMCid: 2668151

Ruiz, J. R., Arteta, D., Buxens, A., Artieda, M., Gómez-Gallego, F., Santiago, C., ... Lucia, A. (2010). Can we identify a power-oriented polygenic profile? J Appl Physiol, 108, 561-566. doi: 10.1152/japplphysiol.01242.2009; PMid: 20044471

Ruiz, J. R., del Valle, M. F., Verde, Z., Díez-Veja, I., Santiago, C., Yvert, T., ... Lucia, A. (2011). ACTN3 R577X polymorphism does not influence explosive leg muscle power in elite volleyball players. Scand J Med Sci Sports, 21, e3441. doi: 10.1111/j.1600-0838.2010.01134.x; PMid:0561285

Scott, R. A., Irving, R., Irwin, l., Morrison, E., Charlton, V., Austin, K., ... Pitsiladis, Y. P. (2009). ACTN3 and ACE genotypes in elite Jamaican and US sprinters. Med Sci Sports Exerc, 42, 107-112. doi: 10.1249/ MSS.0b013e3181ae2bc0; PMid: 20010124 Walsh, P. S., Metzger, D. A., \& Higuchi, R. (1991). Chelex 100 as a medium for simple extraction of DNA for PCR-based typing from forensic material. Biotechniques, 10, 506-513. PMid: 1867860

Yang, N., MacArthur, D. G., Gulbin, J. P., Hahn, A. G., Beggs, A. H., Easteal, S., \& North, K. (2003). ACTN3 genotype is associated with human elite athletic performance. Am J Hum Genet, 73, 627-631. doi: 10.1086/377590; PMid: 12879365; PMCid: 1180686

Zary, J. C. F., \& Fernandes-Filho, J. (2007). Identificação do Perfil Dermatoglífico e Somatotípico dos Atletas de voleibol masculino adulto, juvenil e infanto-juvenil, de alto rendimento no Brasil [Identification and Profile Dermatoglyphic somatotypical Athletes 
volleyball adult male, juvenile and juvenile, high yield in Brazill. R bras Ci e Mov, 15, 53-60.

Zary, J. C., Reis, V. M., Rouboa, A., Silva, A. J., Fernandes, P. R., \& Fernandes Filho, J. (2010). The somatotype and dermatoglyphic profiles of adult, junior and juvenile male Brazilian top- level volleyball players. Sci Sports, 25, 146-152. doi: 10.1016/j.scispo.2009.09.002

Zempo, H., Tanabe, K., Murakami, H., Iemitsu, M., Maeda, S., \& Kuno, S. (2010). ACTN3

Polymorphism Affects Thigh Muscle Area. Int J Sports Med, 31, 138-142. doi: 10.1055/s-00291242808; PMid: 20222007

Received: April 11, 2012

Revision received: Jun 11, 2013

Accepted: Jun 19, 2013

Correspondence to:

Carlos Renato Paz

182 Aderbal Piragibe av., Jaguaribe, João Pessoa city, State of Paraíba,

Brazil

Phone: 00558388500504

E-mail: renatopaz@hotmail.com 